\title{
A REVIEW OF THE EFFECTS OF WASTEWATER ON REINFORCED CONCRETE STRUCTURES IN NIGERIA
}

\author{
K. A. Olonade* \\ DEPARTMENT OF Civil ENGINEERING, OBAFEMI AwOlowo UNIVERSITY, ILE-IFE, OSUN STATE. NIGERIA \\ E-mail address. olonade1431ah@gmail.com
}

\begin{abstract}
This paper reviews the degradation mechanism of wastewater on reinforced concrete structures with a view to finding what needs to be done to salvage these structures. Potential disintegrating agents in wastewater generated in Nigeria were identified and common degradation effects were examined. Regeneration, preventive and corrective techniques were noted. While noting that poor maintenance culture, lack of multidisciplinary research work and high cost of maintenance were major factors responsible for the high rate of deterioration. The paper, therefore, concluded with suggestions that could be employed to salvage these structures from total collapse. One of such approaches is to use admixtures, which could reduce the effect of acidic attack common in wastewater concrete structures.
\end{abstract}

Keyword: Wastewater, reinforced concrete structures, degradation, maintenance.

\section{INTRODUCTION}

The fact that wastewater has detrimental effect on durability of reinforced concrete structures is not disputable. American Concrete Institute (ACI) Committee 201defines durability of Portland cement concrete "as its ability to resist weathering action, chemical attack, abrasion, or any other process of deterioration" [1]. Thus, durable concrete will retain its original form, quality, and serviceability when exposed to its environment.

In most natural environments, concrete is durable. However, concrete is sometimes used in areas where it is exposed to substances that can attack and deteriorate it [2]. Moreso, when reinforced concrete structures are used as transporting media and/or treatment facilities for wastewater; they are exposed to extremely aggressive factors of the environment which could reduce their durability. According to [3] composition of wastewater is a function of its source, which consequently has greater impact on the nature of deterioration expected on reinforced concrete structures.

There is paucity of data on the effect of wastewater generated in Nigeria on concrete structures. This paper attempts to review the nature of wastewater generated in Nigeria and its attendant effect on reinforced concrete structures. This review could create awareness gearing towards concerted research effort in this regard and the need for action to safeguard these structures from total failure.

\section{WASTEWATER IN NIGERIA: GENERATION AND COMPOSITIONS}

Wastewater can mean different things to different people with a large number of definitions in use. However, what appear to be a broader definition is given by [4] as "a combination of one or more of: domestic effluent consisting of blackwater (excreta, urine and faecal sludge) and greywater (kitchen and bathing wastewater); water from commercial establishments and institutions, including hospitals; industrial effluent, storm water and other urban runoff; agricultural, horticultural and aquaculture effluent, either dissolved or as suspended matter. Nevertheless, it is pertinent to note that the nature of wastewater generated is heavily influenced by anthropogenic impact.

Nigeria is mainly an agrarian country. Apart from the south-south geopolitical region of the country that is known for crude oil production, other regions are noted for production of one agricultural product or the other (Figure 1). 
Being the most populous country in Africa, with an estimated population of 170 million and an average density of about 130 persons per sq. km, Nigeria generates large quantities of domestic wastewater.

In its quest for urbanization and industrialization, which are the impetus for economic growth, large quantities of industrial wastewater are equally generated [5] and [6]. Itah in [7] reported that Nigeria generates over $500,000 \mathrm{~m}^{3}$ of wastewater annually.

Different researchers had characterised the nature of wastewater generated in Nigeria. Table 1 summarizes their findings. The table indicates that domestic wastewater contains more of organic substances while industries contribute various amounts of organic and non-organic compounds with heavy metals as well as acidic substances. The subsequent sections of this paper show how these agents, organic and non-organic substances, in the wastewater affect reinforced concrete applications.

\section{REINFORCED CONCRETE STRUCTURES USED IN HANDLING WASTEWATER IN NIGERIA}

Like many other developing countries, handling of wastewater in Nigeria entails transporting the wastewater away from the point of production either to a body of water (Figure 3) or to treatment plant where one exists.

It could also be transported into soakaway and septic tanks in case of domestic wastewater. Though most domestic wastewater is transported through plastic pipes, the chambers receiving the wastes are made of concrete material. On the other hand, municipal and industrial wastewater as well as runoff water are transported through concrete sewers and stored in concrete tanks for possible treatment (Figure 3). Occurrences of concrete degradation in these structures have been recorded in a limited fashion in aeration tanks [16], septic tanks and pumping stations [17], the underside of concrete slabs, and in primary influent channels [18].

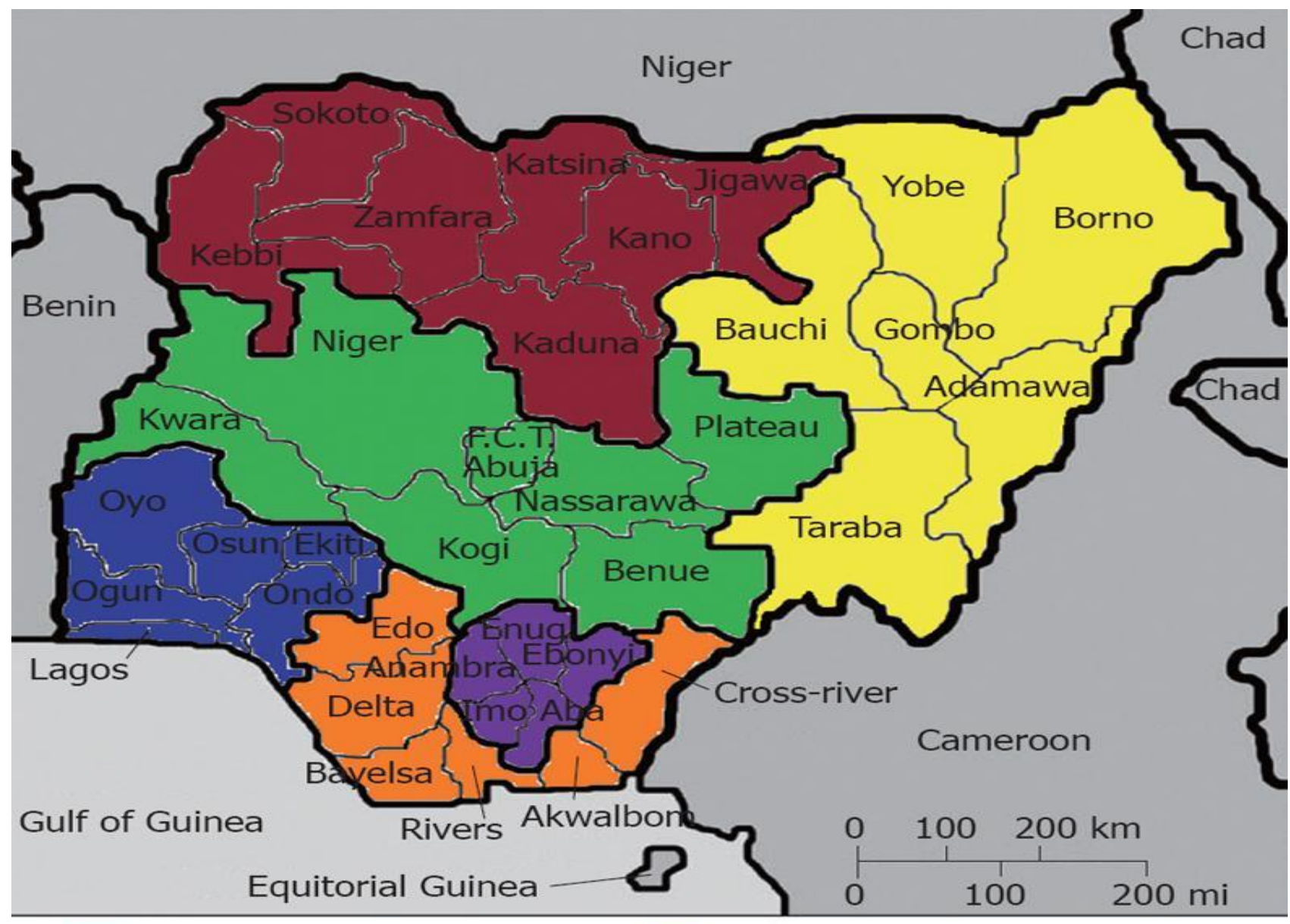

North west
North east
North central

South west

South south

South east

Figure 1: Map of Nigeria Showing the Six Geopolitical Zones [8] 
Table 1: Sources of wastewater generation and their contaminating effects

\begin{tabular}{|c|c|}
\hline Industries & Compositions \\
\hline $\begin{array}{l}\text { Pharmaceutical } \\
\text { industry }\end{array}$ & $\begin{array}{l}\text { Remnants of antibiotics, lipid regulators, anti-inflammatories, anti-epileptics, tranquilizers, and } \\
\text { cosmetic ingredients containing oil and grease with very different chemical structures[9] }\end{array}$ \\
\hline $\begin{array}{l}\text { Soap and } \\
\text { detergent } \\
\text { Industry }\end{array}$ & $\begin{array}{l}\text { Heavy metals such as lead, Zinc and Manganese[10], highly contaminated with organic } \\
\text { compounds which contains significant concentrations of oil and grease amounting to } 563 \mathrm{mg} \mathrm{L-} \\
1[11]\end{array}$ \\
\hline $\begin{array}{l}\text { Paper mill } \\
\text { industry }\end{array}$ & Sugars and lignocelluloses[12] \\
\hline Fertilizer Plant & $\begin{array}{l}\text { High concentration of potentially toxic wastes rich in ammonia-nitrogen, urea, nitrate-nitrogen } \\
\text { orthophosphate-phosphorus [11] }\end{array}$ \\
\hline $\begin{array}{l}\text { Textile mill } \\
\text { effluent }\end{array}$ & $\begin{array}{l}\text { Heavy metals, Starch, waxes, carboxymethyl cellulose (CMC), polyvinyl alcohol(PVA), wetting } \\
\text { agents, Sodium hypochlorite, } \mathrm{NaOH}, \mathrm{H}_{2} \mathrm{O}_{2} \text {, acids, surfactants, }\left(\mathrm{NaSiO}{ }_{2} \text { sodium phosphate, Sodium }\right. \\
\text { hydroxide, cotton wax, reducing agents, oxidizing agents, acetic acid, detergents, wetting agents, } \\
\text { Pastes, urea, starches, gums, oils, binders, cross-linkers, reducing agents, alkali [6] }\end{array}$ \\
\hline Brewery industry & High in carbohydrates, ammonia[12] \\
\hline $\begin{array}{l}\text { Tannery } \\
\text { industrial effluent }\end{array}$ & Chromium (II) contamination levels[12] \\
\hline Soft drink effluent & More acidity with a pH of $6.6 \pm 1.2[13]$ \\
\hline Chemical industry & $\begin{array}{l}\text { Hydroxylbenzene (phenol), chlorobenzene, methylbenzene (toluene) and dimethylbenzene } \\
\text { (xylene) [14] }\end{array}$ \\
\hline Domestic wastes & Decomposable organic matter and undecomposed organic material [14] \\
\hline $\begin{array}{l}\text { Palm oil mill } \\
\text { industry }\end{array}$ & $\begin{array}{l}\text { Organic carbon, nitrogen content }(0.2 \mathrm{~g} / \mathrm{L}) \text { as ammonia nitrogen and } 0.5 \mathrm{~g} / \mathrm{L} \text { total nitrogen [15], } \\
\text { various suspended components including cell walls, organelles, short fibres, a spectrum of } \\
\text { carbohydrates ranging from hemicellulose to simple sugars, a range of nitrogenous compounds } \\
\text { from proteins to amino acids, free organic acids and an assembly of minor organic and mineral } \\
\text { constituents, dark colour [12] }\end{array}$ \\
\hline
\end{tabular}

According to the study of [19], there are only 26 treatment plants located at different parts of the country. All of these are made of reinforced concrete materials. The choice of reinforced concrete material for these structures could be attributed to relative resistance of concrete to water, relatively low cost of construction and ease of maintenance [20]. Nevertheless, wastewater contains disintegrating agents that make the environment very unfavourable for concrete and reinforcing bars.

\section{MECHANISM OF DEGRADATION IN CONCRETE STRUCTURES USED IN WASTEWATER FACILITIES}

Degradation process of reinforced concrete structures as wastewater facilities is a complex phenomenon. Since many factors are involved, it becomes a great challenge to isolate the impact of each of the disintegrating agents found in wastewater. However, substantial efforts by many researchers could give clue into the processes involved. Features of wastewater produced in Nigeria could be broadly classified as containing organic and inorganic substances (Table 1).
Characterization of wastewater from homes and food processing industries in Nigeria indicated that they contain chlorides, nitrogen compounds and a wide variety of organic matters as shown by their high concentration of Biochemical Oxygen Demand (BOD) and Chemical Oxygen Demand (COD). For instance, a total of over 17 million $\mathrm{kg}$ / pollutant load of BOD were discharged into Nigerian coastal environment without any form of treatment [21].

Furthermore, chemical combination of carbon, phosphorus and nitrogen form organic matter in wastewater. The formation of organic matter causes the growth of zooplankton as well as macro benthic invertebrates, which further stimulates the growth of bacteria and fungi [22]. Bacteria and fungi play critical role in breaking down the toxic components of wastewater. This microbiological activity in wastewater produces acidic chemicals that are corrosive to concrete and steel. Parker [23] and Mori et al [24] have long identified bacterial genus Thiobacillusas a major contributor to the deterioration process of concrete sewer pipelines because these organisms are able to oxidize sulphide, elemental sulphur, thiosulfate, and poly thionite, 
resulting in the formation of sulphuric acid $\left(\mathrm{H}_{2} \mathrm{SO}_{4}\right)$. Formation of $\mathrm{H}_{2} \mathrm{SO}_{4}$ in municipal wastewater systems is a two-stage process: bacteria produce sulphide ions and hydrogen sulphide, which are metabolized by other bacteria to produce oxidized sulphur species that react with water to produce $\mathrm{H}_{2} \mathrm{SO}_{4}$.

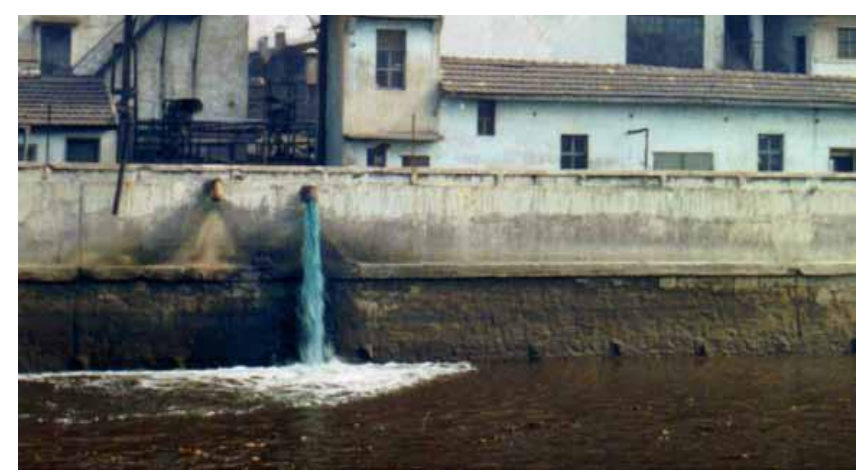

Figure 2: Typical discharging of industrial wastewater in Nigeria [By the Author]

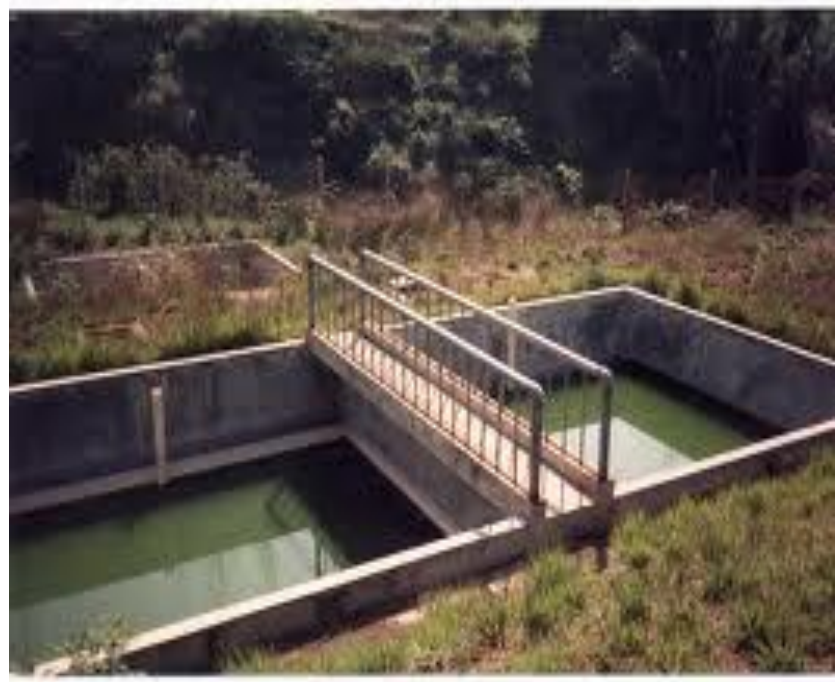

(a)

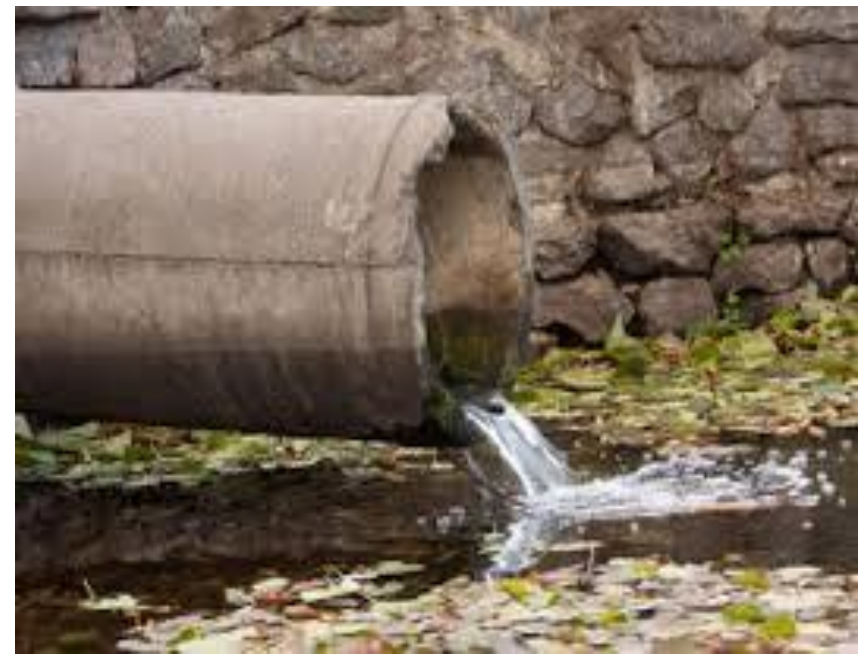

(b)

Figure 3: Handling of wastewater in Nigeria using (a) concrete pipe (b) concrete tank [By the Author]
Sulphuric acid $\left(\mathrm{H}_{2} \mathrm{SO}_{4}\right)$ however, has been implicated as a corrosive agent not only to sewer pipes but also to the treatment facilities [25] and [26].

Attiogbe and Rizkalla [27] and Skalny et al [28] gave a detailed account of the degradation process that occurs when concrete encounter $\mathrm{H}_{2} \mathrm{SO}_{4}$. They reported that $\mathrm{H}_{2} \mathrm{SO}_{4}$ first reacts with the by-product of cement hydration, calcium hydroxide $\left(\mathrm{Ca}(\mathrm{OH})_{2}\right)$, to form calcium sulphate, $\mathrm{CaSO}_{4}$ (Equation 1). When $\mathrm{CaSO}_{4}$ is hydrated, gypsum is formed. The gypsum appears on the surface of concrete pipes or tanks as described by [29] as a white, mushy substance which has no cohesive properties. Furthermore, $\mathrm{H}_{2} \mathrm{SO}_{4}$ attack leads to reaction between the gypsum and calcium aluminate hydrate $\left(\mathrm{C}_{3} \mathrm{~A}\right)$ to form ettringite, as indicated in Equation 2. The overall effect of this reaction leads to weak concrete of no structural importance because both gypsum and ettringite have larger volumes than the compounds they replace resulting in internal pressures, formation of cracks and eventually, the loss of strength [30]. Consequently, the concrete becomes vulnerable to aggressive exposure (Figure 4a).

$$
\begin{aligned}
& \mathrm{H}_{2} \mathrm{SO}_{4}+\mathrm{Ca}(\mathrm{OH})_{2} \\
& \stackrel{\rightarrow \mathrm{CaSO}_{4} \cdot 2 \mathrm{H}_{2} \mathrm{O}(\text { gypsum })}{ } \\
& 3 \mathrm{CaSO}_{4}+3 \mathrm{CaO} \cdot \mathrm{Al}_{2} \mathrm{O}_{3} \cdot 6 \mathrm{H}_{2} \mathrm{O}+25 \mathrm{H}_{2} \mathrm{O} \\
& \rightarrow 3 \mathrm{CaO} \cdot \mathrm{Al}_{2} \mathrm{O}_{3} \cdot 3 \mathrm{CaSO}_{4} \cdot 31 \mathrm{H}_{2} \mathrm{O} \text { (ettringite) }
\end{aligned}
$$

Aesthetics of the concrete is equally affected as microbial activity on organic substance in wastewater supports the growth of moss, algae, lichens and fungi (Figure 4b). Algae and moss have been noted to trigger concrete corrosion due to the humic acids resulting from their putrefaction, and due to the carbon dioxide released after the photosynthesis. Fungi engender a highly acid environment $(\mathrm{pH}=1.9$ $2.8)$, through their gelatinous mycelia, which spread all over the concrete and penetrate deep within its core [31]. This effect results in cracking of concrete which eventually expose reinforcing bar to corrosion. However, there is still scarce research on microbial effect on concrete structures in Nigeria.

Many authors have identified several other substances that are found in wastewater, which have detrimental effect on concrete. These include high concentrations of nitrates, chlorides, sulphates and heavy metals [32], [33], [34] and [35]. 


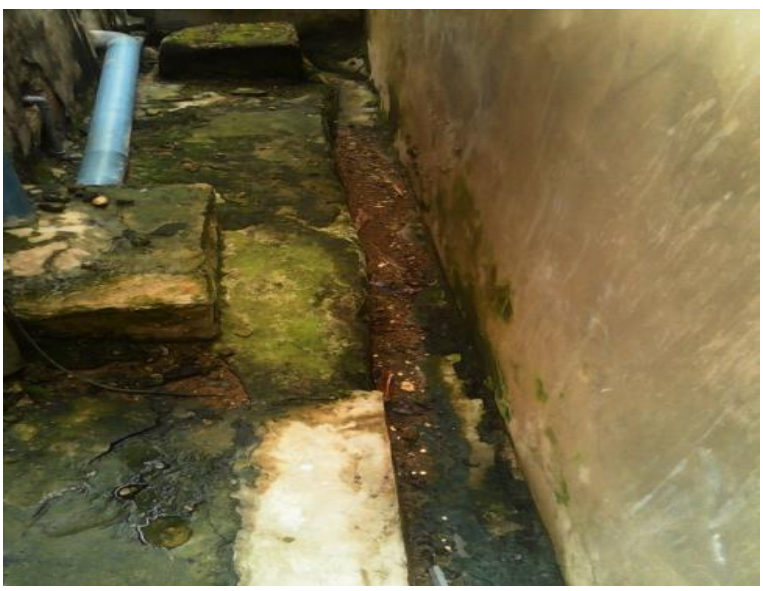

(a)

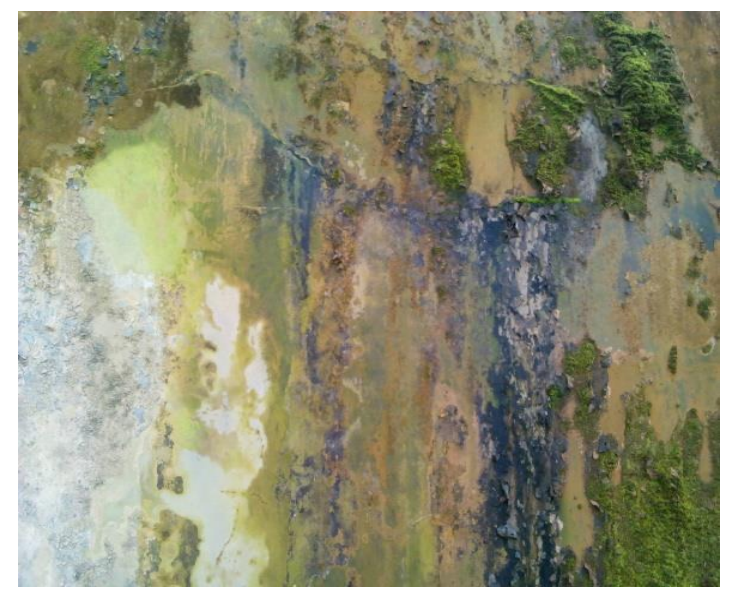

(b)

Figure 4: Typical concrete and steel corrosion (a) growth of algae (b) algae growing into the concrete

\section{PRESERVATION OF CONCRETE STRUCTURES FROM DAMAGING EFFECTS OF WASTEWATER}

Studies have shown that huge amount of fund is lost to degradation of wastewater utilities. While [36] estimated the expenses of repair and maintenance of private and public sewage systems in Germany at about US $\$ 100$ billion, the amount lost to damage of sewers pipes and facilities was estimated as several billions of dollars annually by [37]. In Japan, it was estimated that the bio-deterioration of concrete sewer pipes was approximately 4.3 to $4.7 \mathrm{~mm} / \mathrm{yr}$. equivalent to approximate life of 20 years [38]. However, there is no report, to date, on the amount lost to wastewater facilities in Nigeria. Existing evidence has shown that corrosion and degradation are present in many concrete structures associated with water and wastewater treatment in Nigeria.

The alarming fact is that some of these facilities deteriorate significantly after less than a decade in service. This situation cannot be allowed to continue, especially in the face of the economic condition of the country. Thus, preventive measures should be adopted. Unfortunately, there is scarce research in this regard in the country; the old approach in which the engineer prescribed the concrete strength without considering ways to prevent concrete deterioration process in these facilities must not be allowed to continue. Several researchers outside the shore of the country have reported different techniques in preserving these facilities, which engineers in the country can emulate. Critical review of literatures indicated that approaches used by researchers are categorised into three, namely - use of admixtures, self-healing concrete technology and microbiological prevention.

\subsection{Use of Admixtures in Protecting Wastewater Concrete Structures}

Admixtures are often used to modify the property of concrete to meet intended performance. Extensive review of literature showed that mineral admixtures and pozzolanic materials (natural and artificial) are used. [39] investigated performance of five admixtures (Silica fume, Metakaolin, organic corrosion inhibitor, Caltite and Xypex) in preventing $\mathrm{H}_{2} \mathrm{SO}_{4}$ attack, which is common to concrete sewer pipes. They reported that all the admixtures contributed to increased compressive strength and low porosity except silica fume. Although silica fume effectively increased compressive strength and reduced the porosity of concrete, its contribution to the resistance of concrete to $\mathrm{H}_{2} \mathrm{SO}_{4}$ was minor. Also of interest is the performance of cements containing additions of GGBS (ground granulated blast-furnace slag) which, when mixed with Portland cement, has been proven to possess an inherent sulphate resisting capability [40] and [41].

Meanwhile, in Nigeria, mineral admixtures are seldom used because they are not readily available or expensive leading to high cost of construction. Being an agrarian country, ashes of some agricultural wastes such as cassava peels, corn cobs, groundnut Husk, coconut and bambara groundnut shell have been reported to be potential pozzolanic materials [42], [43], [44] and [45]. However, the use of these ashes in concrete is yet to be well accepted even in normal construction, not to mention wastewater concrete structures. Another major challenge is the inadequacy of experimental test methods to analyse biological corrosion in wastewater environment taking into consideration simultaneous biological and acidic attack. 


\subsection{Self-Healing Technology}

Though the use of self-healing properties was first reported in polymeric materials in 1969 [46], but selfhealing in concrete is as old as concrete itself. Concrete possesses some natural autogenous healing properties. During the hydration of cement and/or carbonation of $\mathrm{Ca}(\mathrm{OH})_{2}$ as well as alkali-silica reaction, cracks may heal after some time.

Recent developments in the field of concrete durability have led to a renewed interest in selfhealing properties of concrete. Self-healing in cementitious materials can be classified broadly into three groups: intrinsic healing, capsule based healing and vascular healing, in accordance with approaches which originate from self-healing of polymers [46]. [47] presented state-of-the art review on the application of self-healing in cementitious materials. They gave account of different approaches to selfhealing, as well as the pros and cons of each technique. They cited several works of researchers showing the potentials of improving concrete performance using self-healing techniques, especially in severe environments.

\subsection{Microbiological Technique}

Sulphate reducing anaerobic bacteria such as Desulfovibrio converts sulphate in wastewater to sulphide, which is later converted to $\mathrm{H}_{2} \mathrm{SO}_{4}$. In [48], it was reported that these bacteria function and grow well when dissolved oxygen levels of the wastewater approaches zero. In the same vein, [49] and [50] proposed that sulphide build-up could not occur when dissolved oxygen levels were greater than $0.5 \mathrm{mg} / \mathrm{l}$ and $0.1 \mathrm{mg} / \mathrm{l}$ respectively. Above these oxygen levels, corrosion will not occur. To achieve increased oxygen levels, injection of air in force mains, inverted siphons, U-tubes, hydraulic falls, and side streams is proposed [51]. The use of bio films has been found to be very effective [52], the technology of which is fully described by [53]. Bacteria and enzyme that could prey on sulphate reducing bacteria are cultured within the wastewater containing concrete structures [54].

\section{CONCLUSION}

i. Nigeria generates large volume of wastewater and that many of the concrete structures used in handling the waste are fast degrading due to the deteriorating impact of wastewater and poor maintenance.

ii. Extensive research works have been reported on characterisation of wastewater generated in
Nigeria. However, the characterisation was with a view to treating the wastes in order to safeguard public health rather than studying the effect on concrete.

iii. Most techniques required in preserving wastewater reinforced concrete structures are not available locally and where available are not cost effective.

iv. Further research is needed to characterise wastewater generated in Nigeria with the purpose of identifying the classes of sulphate reducing bacteria and other concrete degrading agents.

v. Studies aimed at quantifying the damaging effect of wastewater generated in Nigeria on sewer pipes and other concrete wastewater utilities will require concerted efforts and multidisciplinary approach.

vi. A key policy priority should therefore be to encourage the use of pozzolanic materials that could resist sulphuric acid attack in concrete.

\section{REFERENCES}

[1] ACI Committee 201. Guide to durable concrete. $A C I$ Manual of Concrete Practice. 201.2 R-08. 2008.

[2] Kerkhoff, B. Effects of substances on concrete and guide to protective treatments, concrete thinking for a sustainable world. Portland cement Association, Skokie, Illinois, USA. 2002

[3] Glasser, F. P., March and, J. and Samson E. Durability of concrete - degradation phenomena involving detrimental chemical reactions. Cement a. Concr. Res., Vol. 38,Number2,2008, pp. 226-246.

[4] Raschid-Sally, L.; Jayakody, P. Drivers and characteristics of wastewater agriculture in developing countries: Results from a global assessment Colombo, Sri Lanka. International Water Management Institute, IWMI Research Report 127. 2008

[5] Aina E. O. A. Halting industrial pollution in Nigeria which way FEPA. In: Towards industrial pollution abatement in Nigeria. Aina E. O. A. and Adedipe N.O. (Eds), 1992, pp. 13-19.

[6] Adeyeye E. I. Assessment of the physico-chemical status of a textile industry. Pak. J. Sci. Vol. 45, Number 1, 2002, pp. 10-16.

[7] Itah, A. Y. Creating public awareness in environmental and public health education. Proceedings of Teachers' Association (STAN).1998, pp. 186 - 189.

[8] 
eopolitical+zones+in+nigeria\&biw

$=1366 \&$ bih $=657 \&$ source $=\operatorname{lnms\& tbm}=\mathrm{isch} \& \mathrm{sa}=\mathrm{X}$ \&ved=0ahUKEwi54v406jJAhUEA3MKHUbQBuAQ_ AUIBigB\#imgrc $=0$ Ycd83R9mYsggM\%3A.Retrieve d on 20th June, 2015.

[9] Lateef, A. The microbiology of pharmaceutical effluent and its public health implications. World J. MicrobiolBiotechnol. Vol. 20, 2004, pp. 167-171.

[10] Kanu, I., Achi, O. K., Ezeronye, O. U. and Anyanwu E. C. Seasonal variation in bacterial heavy metal biosorption in water samples from Eziama River near soap and brewery industries and the environmental health implications. Int. J. Environ. Sci. Tech. Vol. 3, Number 1, 2006, pp. 95-102.

[11] El-Gohary, F. A., Abo-Elela S.I. and Ali H. I. Management of wastewater from soap and food industries: a case study. Sci Total Environ. Vol. 66, 1987, pp. 203-212.

[12] Kanu I and Achi, O. K. Industrial effluents and their impact on water quality of receiving rivers in Nigeria. Journal of Applied Technology in Environmental Sanitation. Vol. 1, Number 1, 2011, pp. $75-86$.

[13] Ibekwe, V. I. Nwaiwu, O. I. and Offorbuike, J.O. Bacteriological and physicochemical qualities of wastewater from a bottling company in Owerri, Nigeria. Global J. Environ. Sci Vol. 3,2004, pp. 5154

[14] Odokuma, L. and Oliwe, O. S. I. Toxicity of substituted benzene derivatives to four chemolithotrophic bacteria isolated from the New Calabar River. Global J Environ Sci. Vol. 2, Number2, 2003, pp. 72-77.

[15] Ma, A. N. Environmental management for the palm oil industry. Palm Oil Dev. Vol. 30 2000, pp. 1-9

[16] Barbosa V. L, Burgess, J. E., Darke, K. and Stuetz, R. M. Activated sludge biotreatment of sulphurous waste emissions. Rev EnvSci Biotech. Vol. 1, Number4, 2002, pp. 345-362.

[17] Saricimen H, Shameem M, Barry M. S., Ibrahim M. and Abbasi T. A. Durability of proprietary cementitious materials for use in wastewater transport systems. CemConcr Comp. Vol. 25, Number 4, 2011, pp. 421-427.

[18] Stufflebean J. Report on bids and award of contract for the San José / Santa Clara water pollution control plant. FY 2007/2008 CIP, San José, California, 2007.

[19] Adesogan, S. Sewage technology in Nigeria: a pragmatic approach. Science Journal of Environmental Engineering Research, 2013:1-9. Doi: $10.7237 /$ sjeer/266, 2013.

[20] Mehta P. K. and Monteiro P. J. M. Concrete: microstructure, properties, and materials, $3^{\text {rd }}$ Ed., the McGraw-Hill Companies, Inc., United States of America. 2006, pp 1 -684.

[21] Siyanbola, T. O., Ajanaku, K. O., James, O. O., Olugbuyiro, J. A. O. and Adekoya, J. O. Physicochemical characteristics of industrial effluents in Lagos State, Nigeria. G. J. P\&A Sc and Tech. Vol. 1, 2011, pp. $49-54$.

[22] Adigun, B. A. Water quality management in agriculture and freshwater zooplankton production for use in fish hatcheries. National Institute for Freshwater, New Bussa, Niger State. 2005 , pp. $23-30$.

[23] Parker C. D. The isolation of a species of bacterium associated with the corrosion of concrete exposed to atmospheres containing hydrogen sulphide. Aust J ExpBiol Med Sci. Vol. 23, 1945, pp. 81-90.

[24] Mori T, Nonaka T, TazakiK, Koga M, Hikosaka Y, Noda S. Interactions of nutrients, moisture and $\mathrm{pH}$ on microbial corrosion of concrete sewer pipes. Water Res. Vol. 26, Number1, 1992, pp. 29-37.

[25] Idriss, A. F., Negi, S.C., Jofriet, J. C. and Hayward, G. L. Corrosion of steel reinforcement in mortar specimens exposed to hydrogen sulphide. J Agr Eng Res Vol. 79, Number3, 2001, pp. 223-230.

[26] Vincke, E. , Verstichel, S.,Monteny, J. and Verstraete W. A new test procedure for biogenic sulfuric acid corrosion of concrete. Biodegradation. Vol. 10, Number6, 1999, pp. 421-428.

[27] Attiogbe E. K., Rizkalla S. H. Response of concrete to sulfuric acid attack.ACI Mater Journal, Vol. 84, Number6, 1988, pp. 481-488.

[28] Skalny, J., Marchand, J. and Odler I. Sulfate attack on concrete. London, Spon Press. 2002.

[29] Davis, J. L., Nica D., Shields, K., and Roberts, D.J. Analysis of concrete from corroded sewer pipe. IntBiodeterBiodegr. Vol. 42, Number 1, 1998, pp. 75-84.

[30] Monteny, N., Debelie, E., Vinke, V. and Taerwe, L. Chemical and microbiological test to simulate sulphuric acid corrosion of polymer-modified concrete". Cement and Concrete Research, Vol. 31, Number9, 2001, pp. 1359-1365.

[31] Petru, M., Răzvan, G., Bogdan, R. And Vladimir, C. Aggressive influences of water from wastewater treatment plants on reinforced concrete members. Bul. Inst. Polit. Iaşi. Vol. LVII Number LXI, 2011, pp. 55-63.

[32] Mtallib, M. O. A. Compressive strength of concrete in contact with nitrate-based substances. Proceeding of the Millennium Conference building in the 21st century. Department of Building, Ahmadu Bello University, Zaria. Nigeria. 2002, pp. 102-111.

[33] Cement Concrete \& Aggregates Australia. Report on chloride resistance of concrete, 2009. 
[34] Corral-Higuera, R., Arredondo-Rea S. P., NeriFlores M. A., Gómez-Soberón, J. M., AlmerayaCalderón F., Castorena-González J. H. and Almaral-Sánchez, J. L. Sulfate attack and reinforcement corrosion in concrete with recycled concrete aggregates and supplementary cementing materials. Int. J. Electrochem. Sci.,Vol. 6, 2011, pp. $613-621$.

[35] Madhusudana Reddy. B., Reddy Babu. G and Ramana Reddy, I.V. Effect of heavy metal present in mixing water on properties and sulphate attack on blended cement mortar. International Journal of Civil and Structural Engineering.2011, pp. 1 - 4.

[36] Kaempfer W. and Berndt M. Estimation of service life of concrete pipes in sewer networks. Proceedings of the $8^{\text {th }}$ Conference on Durability of Building Materials and Components, National Research Council of Canada, Vol. 1, 1999, pp. 3645.

[37] Brongers M., Koch, G. and Thompson, N. Corrosion costs and preventive strategies in the United States. Federal Highway Administration, Washington, DC, Report FHWA-RD- 01-156. 2001

[38] Little, B. J., and Lee J. S. Microbiologically influenced corrosion. Wiley Interscience. 2007

[39] Hewayde, E., Nehdi, M. L. Allouche, E. and Nakhla, G. Using concrete admixtures for sulphuric acid resistance. Proceedings of the Institution of Civil Engineers Construction Materials (doi: 10.1680/coma.2007.160.1.25). 2007, pp. 25-35.

[40] Mehta P.K, Burrows RW. Concrete in aggressive ground. Building Research Establishment.BRE Special Digest. 2nd Ed. 2003, pp. 1 - 15.

[41] Higgins, D. D. Increased sulfate resistance of ggbs concrete in the presence of carbonate. CemConcr Comp. Vol. 25, Number8, 2003, pp. 913-919. http://www.wjgnet.com/1949-

8462/full/v4/i12/WJC-4-327-g002.jpg. Retrieved on 6th Dec. 2014.

[42] Olonade, K. A., Olajumoke, A. M, Omotosho A. O. and Oyekunle F. A. Effects of Sulphuric Acid on the Compressive Strength of Blended Cement/Cassava Peel Ash Concrete. Construction Materials and Structures, S.O. Ekolu et al. (Eds.), IOS Press, 764 - 771, 2014.Doi: 10.3233/978-161499-466-4-764.

[43] Adesanya, D. A. and Raheem, A.A. A study of the permeability and acid attack of corn cob ash blended cements. Constr. Build. Mater. Vol. 24, Number 3, 2010, pp. 403-409.
[44] Alabadan, B. A., Olutoye, M. A., Abolarin, M. S. and Zakariya, M. Partial replacement of ordinary Portland cement (OPC) with bambara groundnut shell ash (BGSA) in concrete. Leonardo Electronic Journal of Practices and Technologies, Vol. 6, 2005, pp. 43-48.

[45] Ketkukah, T. S. and Ndububa, E. E. Groundnut husk ash (gha) as a pozzolana material in mortar. International Journal of Science and Technological Research, Vol. 3, Number 2, 2006, pp. 209-214.

[46] Blaiszik, B. J., Kramer, S. L. B. Olugebefola, S.C., Moore, J. S., Sottos, N. R. and White, S.R. Selfhealing polymers and composites. Annu. Rev. Mater. Res. Vol. 40, 2010, pp. 179-211.

[47] Kim Van Tittelboom and Nele De Belie. Self-healing in cementitious materials-A review. Materials. Vol. 6, 2013, pp. 2182-2217. doi: $10.3390 / \mathrm{ma} 6062182$

[48] Mohan. S. V., Rao. N.C., Prasad. K.K. and Sarma, P.N. Bioaugmentation of an anaerobic sequencing batch biofilm reactor (AnSBBR) with immobilized sulphate reducing bacteria (SRB) for the treatment of sulphate bearing chemical wastewater. Process Biochem. Vol. 40, Number8, 2005, pp. 2849-2857.

[49] Ayoub, G. M., Azar, N. E., Fadel, M. and Hamad, B. Assessment of hydrogen sulfide corrosion of cementitious sewer pipes: a case study. Urban Water J. Vol. 1, Number1, 2004, pp. 39-53.

[50] Hewayde, E., Nehdi, M., Allouche, E. and Nakhla, G. Effect of geopolymer cement on microstructure, compressive strength and sulfuric acid resistance of concrete. Mag Concr Res. Vol. 58, Number5, 2006, pp. 321-331.

[51] Technical Evaluation Committee. Corrosion control measures for sewerage structures. Publication of the Japan Sewage Works Agency, 200709. 2001

[52] Geoghegan, M., Andrews, J. S., Biggs, C. A., Eboigbodin, K. E., Elliott, D. R., Rolfe, S., Scholes, J., Ojeda, J. J., Romero-Gonzalez, M. E., and Edyvean R. G. J. The polymer physics and chemistry of microbial cell attachment and adhesion. Faraday Discussions. Vol. 139, 2008, pp. 85-103.

[53] Beyenal, H. and Lewandowski Z. Internal and external mass transfer in biofilms grown at various flow velocities. Biotechnology progress Vol.18, Number 1, 2002, pp. 55-61.

[54] William E. S and Leonard W.B. Corrosion control in concrete pipe and manhole. Technical presentation of Water Environmental Federation, Orlando, Florida, 1998, pp. 1 - 125. 